\title{
MONITORING THE EFFECTS OF VARIOUS COMBINATION OF SPECIFIC DRUG THERAPIES AT DIFFERENT STAGES OF ALZHEIMER'S DEMENTIA
}

\author{
LAVINIA PURZA ${ }^{1,2}$, MOHAMED ABDEL-DAIM $^{3,4}$, ADRIANA BELBA $^{2}$, CIPRIAN IOVAN $^{2 *}$, \\ ADRIAN BUMBU ${ }^{2}$, LIVIU LAZĂR ${ }^{2}$, SIMONA BUNGĂU ${ }^{2}$, DELIA MIRELA ȚIȚ ${ }^{2}$ \\ ${ }^{1}$ University of Oradea, Doctoral School of Biomedical Sciences, 1 Universităţii Street, 410087, Oradea, Romania \\ ${ }^{2}$ University of Oradea, Faculty of Medicine and Pharmacy, 10 P-ţa 1 Decembrie Street, 410073, Oradea, Romania \\ ${ }^{3}$ Suez Canal University, Faculty of Veterinary Medicine, Pharmacology Department, Egypt \\ ${ }^{4}$ Yokohama City University, Department of Ophthalmology and Micro-Technology, Yokohama, Japan
}

*corresponding author: dr.iovan@biostandard.ro

Manuscript received: October 2018

\begin{abstract}
We have studied the effects of various combinations of specific drug therapies on patients with Alzheimer's dementia. The study was conducted over a 12-week period, with initial, after 4, 8, and 12-weeks assessment. A number of 140 patients with Alzheimer's dementia were assessed observing the clinical manifestations, the therapeutic measures that were applied and the changes in the response to treatment. Mini-Mental State Examination (MMSE) was used to monitor the cognitive functionality evolution of the studied patients. The depreciation of the MMSE score was observed in 2.94\% of the patients registering a mild impairment, in 6.02\% - a moderate impairment and $17.39 \%$ - a severe impairment. The greatest depreciation effect was achieved with memantine in monotherapy $(\mathrm{ES}=0.24)$, and the lowest - with donepezil therapy in combination with memantine $(\mathrm{ES}=0.24)$. Our results prove that specific anti-dementia treatment is effective for the treatment of cognitive impairment, especially if it is instituted at the onset of the disease.
\end{abstract}

\section{Rezumat}

$\mathrm{Au}$ fost studiate efectele diferitelor terapii specifice asupra pacienților cu demență Alzheimer. Studiul a fost efectuat pe o perioadă de 12 săptămâni, cu evaluare inițială, după 4, 8 și 12 săptămâni. Un număr de 140 de pacienți cu demență Alzheimer au fost evaluați, fiind urmărite manifestările clinice, măsurile terapeutice care au fost aplicate și modificările răspunsului la tratament. Examinarea Mini-Mental State (MMSE) a fost utilizată pentru monitorizarea evoluției funcționalității cognitive a pacienților. S-a observat deprecierea scorului MMSE la 2,94\% dintre pacienții aflați în faza uşoară a bolii, la $6,02 \%$ dintre cei în faza moderată și $17,39 \%$ dintre cei în faza severă. Cel mai mare efect de depreciere a fost obținut cu memantină în monoterapie $(\mathrm{ES}=0,24)$ și cel mai mic - în terapia cu donepezil în asociere cu memantină $(\mathrm{ES}=0,24)$. Rezultatele obținute demonstrează că tratamentul specific anti-demență este eficient pentru ameliorarea tulburărilor cognitive, mai ales dacă este instituit la debutul bolii.

Keywords: Alzheimer's dementia, cognitive therapy, MMSE, memantine, donepezil

\section{Introduction}

Alzheimer's dementia is a degenerative cognitive disorder with progressive evolution, which is a major health problem for the elderly, changing in varying degrees all aspects of the patient's life, a disabling disease that causes suffering to both patients and their families. The neuropathological prints of Alzheimer's disease are the presence of neuritic plaque (NP) and neurofibrillary tangles (NFT), but these lesions are not characteristic to Alzheimer's dementia, they occur in other various neurodegenerative diseases $[1,10$, $11,22,26]$.

The goal of the treatment in dementia has always been a complex issue; it has changed from an exclusive focus on clinical symptomatology to the interest for social aspects with social variables, professional and cognitive antecedents. A therapeutically effective management is dependent on the ability of the physician to diagnose the suffering early, to combine several therapeutic methods, and to appreciate the factors that could affect the prognosis of suffering $[5,21,28]$.

In general, a low educational level and other socioeconomic factors have been associated with a high risk of obesity, sedentary lifestyle, diabetes, hypertension, dyslipidaemia and metabolic syndrome, all these increase the risk of VD (vascular dementia) and AD (Alzheimer's dementia) [12, 18, 19, 27]. Major risk factors identified in a review of 41 studies in which Alzheimer's dementia was the most prevalent 
type of dementia included older age, female gender, cardiovascular disease and illiteracy [17].

The objectives of the present study are to assess the prevalence of risk factors for the elderly population and to monitor the effects of various combinations of specific drug therapies.

\section{Materials and Methods}

\section{Materials}

A number of 140 patients that were diagnosed with Alzheimer's dementia and were admitted to the psychiatric departments of the "Gavril Curteanu" Clinical Hospital in Oradea, Romania, during the period 2012 - 2014, were recruited for the study. The research was conducted in accordance with the WMA Declaration of Ethical Helsinki-Medical Research Involving Human Principles for Subjects, and was approved by the Ethics Commission of the Council of Medicine and Pharmacy Faculty, University of Oradea, Romania. The patients that were included in the study were randomly selected of the patients hospitalized in the psychiatric departments of the hospital, diagnosed with dementia according to current regulation, their treatment was determined by the specialist physician taking into account the medical history of the patients and the associated pathologies. The inclusion criteria in the study were: patients with diagnosis of Alzheimer's dementia and MMSE score lower than 24. Patients with other type of dementia were excluded from the study. For each patient an informed consent was signed by his caregiver. The clinical manifestations, the therapeutic measures that were applied and the changes in the response to the treatment were observed. A prospective study was performed over a 12 -weeks period, with patients being evaluated initially, and at 4,8 and 12-weeks, respectively.

Fifty-three cases $(37.86 \%)$ followed the combined treatment with donepezil and memantine (doses and schedule of administration varied according to

treatment response and disease progression for each patient as follows: donepezil $10 \mathrm{mg} \mathrm{1-0-0}$ and memantine

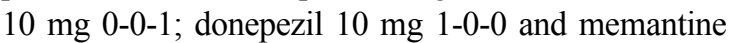
$10 \mathrm{mg} \mathrm{1/2-0-1}$; donepezil $5 \mathrm{mg} \mathrm{1-0-0}$ and memantine $10 \mathrm{mg} \mathrm{0-0-1}$; donepezil $5 \mathrm{mg} \mathrm{1-0-0}$ and memantine

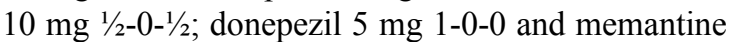

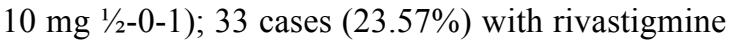
and memantine (daily dose of rivastigmine $6-12$ $\mathrm{mg}$, memantine $10-20 \mathrm{mg}$ depending on disease progression); 29 cases $(20.71 \%$ ) only with memantine $10-20 \mathrm{mg}$ daily (doses and schedule according to treatment response and disease progression for each patient memantine $10 \mathrm{mg}$ was administered as follows: $0-0-1 ; 1 / 2-0-1 ; 1-0-1) ; 25$ cases $(17.86 \%)$ with galantamine and memantine (galantamine $16-24 \mathrm{mg}$ daily, memantine 10 - $20 \mathrm{mg}$ daily).

There were associated preparations of Ginkgo biloba to improve brain circulation; vitamin $\mathrm{E}$ was used to slow the progression of dementia as an antioxidant. The depressive syndrome was treated with SSRI antidepressants (fluvoxamine, fluoxetine, paroxetine). Patients with psychotic symptoms and those with behavioural disorders received treatment with atypical antipsychotics like risperidone $0.5-1 \mathrm{mg}$ /day and tiapridum $50 \mathrm{mg} /$ day. The treatment of associated diseases implied in addition to medication and general care (of eating, dietary compliance, and personal hygiene), the prevention of inter-current infections. In order to stimulate relational life, in some cases, attempts of occupational therapy, socio-therapy, supportive, group, and family psychotherapy were implemented alongside.

Cognitive functionality was evaluated using the MMSE scale (Mini-Mental State Examination) [20]. MMSE comprises 30 items and evaluates the patient's attention and computation, orientation, language, recording, memory and visual construction. The final score is in the range 0 - 30. Table I presents the data relating to stages of the disease according to MMSE score.

Table I

Stages of the disease according to MMSE score [20]

\begin{tabular}{|c|c|c|}
\hline MMSE score & Stage of impairment & Characteristics \\
\hline 30 & Normal & Without symptoms \\
\hline $24-27$ & Initial cognitive & Mnesic disorders \\
\hline $21-23$ & Mild & Memory and thinking impairment outlined \\
\hline $18-20$ & Moderate & Clear cognitive deficits \\
\hline $15-17$ & Marked & $\begin{array}{c}\text { Cognitive and psychiatric symptoms } \\
\text { Require a degree of assistance }\end{array}$ \\
\hline $12-16$ & Severe & Needs support for everyday activities \\
\hline $0-11$ & Serious & Requires institutionalized assistance \\
\hline
\end{tabular}

Patients that obtained a score lower than 24 during the screening period were included in the study. Clinical manifestations, therapeutic measures that were applied to patients and important changes in response to the treatment were followed by applying the MMSE at 4, 8 and 12-weeks.

\section{Statistical analysis}

There were calculated the parameters averages, frequency ranges, standard deviations, statistical significance tests by the Student method (t-test) and 
$\chi^{2}$. To measure sensitivity to change, we used the statistical calculation system "effect size" (ES).

\section{Results and Discussion}

Demographic and clinical characteristics of the patients are presented in Table II.

Table II

Demographic and clinical characteristics of the

\begin{tabular}{|c|c|c|c|}
\hline \multirow{2}{*}{\multicolumn{2}{|c|}{ Characteristics }} & \multicolumn{2}{|c|}{ Patients } \\
\hline & & \multirow{2}{*}{$\begin{array}{c}\text { No. } \\
26 \\
\end{array}$} & \multirow{2}{*}{$\begin{array}{c}\% \\
18.57 \\
\end{array}$} \\
\hline Gender & Male & & \\
\hline Gender & Female & 114 & 81.43 \\
\hline \multirow{2}{*}{ Provenience area } & Urban & 76 & 54.29 \\
\hline & Rural & 64 & 45.71 \\
\hline \multirow{7}{*}{$\begin{array}{l}\text { Age groups } \\
\text { (years) }\end{array}$} & $\leq 65$ & 2 & 1.43 \\
\hline & $66-70$ & 12 & 8.57 \\
\hline & $71-75$ & 38 & 27,14 \\
\hline & $76-80$ & 36 & 25.71 \\
\hline & $81-85$ & 33 & 23.57 \\
\hline & $86-90$ & 10 & 7.14 \\
\hline & $>90$ & 9 & 6.43 \\
\hline \multirow{2}{*}{ Self-care capacity } & Capable & 58 & 41.43 \\
\hline & Incapable & 82 & 58.57 \\
\hline \multirow{3}{*}{ Stage of impairment } & Mild & 34 & 24.29 \\
\hline & Moderate & 83 & 59.29 \\
\hline & Severe & 23 & 16.43 \\
\hline
\end{tabular}

The most frequent comorbidities were atherosclerosis, ischemic cardiopathy, hypertension and type II diabetes, all being present in significant percentages, according to Table III.

Table III

Distribution of cases according to comorbidities

\begin{tabular}{|l|c|c|}
\hline \multirow{2}{*}{\multicolumn{1}{|c|}{ Comorbidities }} & \multicolumn{2}{c|}{ Patients } \\
\cline { 2 - 3 } & No. & \% \\
\hline Generalized atherosclerosis & 50 & 35.71 \\
\hline Ischemic cardiopathy & 38 & 27.14 \\
\hline Hypertension & 22 & 15.71 \\
\hline Type 2 diabetes & 14 & 10.00 \\
\hline Heart failure & 8 & 5.71 \\
\hline Parkinson's disease & 4 & 2.86 \\
\hline Cachexia & 4 & 2.86 \\
\hline
\end{tabular}

In the mild impairment stage, there was only one MMSE score depreciation at 12 weeks $(2.94 \%)$, the score value remaining in the mild stage of the disease. In the moderate stage of the disease we recorded depreciations of the scores in all three evaluations, of which two cases passed in a severe state. At four weeks there was a case of depreciation of score (1.20\%), and at 8 and 12 weeks 2 cases $(2.41 \%)$.

In the severe stage of the disease we recorded depreciation of the score in all three evaluations, one case at 4 and 8 weeks, respectively, $(4.35 \%)$ and two cases at 12 weeks $(8.70 \%)$. Thus, after 12 weeks of treatment, we recorded the depreciation of the score in $2.94 \%$ of the patients with mild impairment initially, at $6.02 \%$ of those with moderate stage and at $17.39 \%$ of those with severe disease; results of our study are presented in Table IV.

Table IV

Share of cases aggravated by stage

\begin{tabular}{|l|l|c|c|}
\hline \multirow{4}{*}{ Evaluation } & \multirow{2}{*}{ Impairment } & \multicolumn{2}{|c|}{ Patients } \\
\cline { 2 - 4 } At 4 weeks & Mo. & $\mathbf{\%}$ \\
\hline & Moderate & 1 & 1.20 \\
\cline { 2 - 4 } & Severe & 1 & 4.35 \\
\cline { 2 - 4 } & Total & 2 & 1.43 \\
\hline \multirow{4}{*}{ At 8 weeks } & Mild & 0 & 0.00 \\
\cline { 2 - 4 } & Moderate & 2 & 2.41 \\
\cline { 2 - 4 } & Severe & 1 & 4.35 \\
\cline { 2 - 4 } & Total & 3 & 2.14 \\
\hline \multirow{4}{*}{ Total } & Mild & 1 & 2.49 \\
\cline { 2 - 4 } & Moderate & 2 & 2.41 \\
\cline { 2 - 4 } & Severe & 2 & 8.70 \\
\cline { 2 - 4 } & Total & 5 & 3.57 \\
\hline & Mild & 1 & 2.94 \\
\cline { 2 - 4 } & Moderate & 5 & 6.02 \\
\cline { 2 - 4 } & Severe & 4 & 17.39 \\
\cline { 2 - 4 } & Total & 10 & 7.14 \\
\hline
\end{tabular}

We noted that the treatment effect in all three evaluations is very low ( $\mathrm{ES}=0.04$ at 4 weeks, $\mathrm{ES}=0.05$ at 8 weeks, ES $=0.07$ at 12 weeks). A certain stagnation of disease progress after a 4-week therapy was noted. The treatment effect at 12 weeks compared to the baseline MMSE score is also very low (ES $=0.07)$, resulting in the treatment application having a disease control effect over a longer period of time (Table V).

Table V

Evolution of the MMSE score

\begin{tabular}{|l|c|c|}
\hline \multicolumn{1}{|c|}{ Evaluation } & MMSE score & ES \\
\hline Baseline & $16.45 \pm 5.21$ & - \\
\hline At 4 weeks & $16.25 \pm 5.03$ & 0.04 \\
\hline At 8 weeks & $16.00 \pm 4.89$ & 0.05 \\
\hline At 12 weeks & $15.66 \pm 4.76$ & 0.07 \\
\hline
\end{tabular}

Values are represented as mean \pm SD $(n=140$ patients in study group)

In the initial assessment, regardless of the type of treatment, most patients had the moderate form of disease $(58.49 \%-60.61 \%)$, followed by the mild form $(24.00 \%-24.53 \%)$. There were no significant differences in the prevalence of disease stages ( $p>$ 0.05) (Table VI).

Regarding the evolution, the two cases that went from moderate to severe stage followed memantine treatment in monotherapy. Regardless of the therapy followed, the treatment slightly managed very little to overcome the MMSE score depreciation. However, the greatest depreciation effect was achieved with memantine in monotherapy $(\mathrm{ES}=0.24)$, and the lowest with donepezil therapy in combination with memantine $(\mathrm{ES}=0.24)$ as it is presented in Table VII. 
FARMACIA, 2019, Vol. 67, 3

Table VI

Distribution of patients by treatment and impairment

\begin{tabular}{|l|l|c|c|}
\hline \multirow{2}{*}{ Treatment } & Impairment & \multicolumn{2}{|c|}{ Patients } \\
\cline { 2 - 4 } & & No. & $\mathbf{\%}$ \\
\hline \multirow{3}{*}{$\begin{array}{l}\text { Donepezil } \\
\text { with Memantine }\end{array}$} & Mild & 13 & 24.53 \\
\cline { 2 - 4 } & Moderate & 31 & 58.49 \\
\cline { 2 - 4 } & Severe & 9 & 16.98 \\
\hline \multirow{2}{*}{$\begin{array}{l}\text { Rivastigmine with } \\
\text { Memantine }\end{array}$} & Mild & 8 & 24.24 \\
\cline { 2 - 4 } & Moderate & 20 & 60.61 \\
\cline { 2 - 4 } & Severe & 5 & 15.15 \\
\hline \multirow{3}{*}{$\begin{array}{l}\text { Galantamine with } \\
\text { Memantine }\end{array}$} & Mild & 6 & 24.00 \\
\cline { 2 - 4 } & Moderate & 15 & 60.00 \\
\cline { 2 - 4 } & Severe & 4 & 16.00 \\
\hline \multirow{3}{*}{ Memantine } & Mild & 7 & 24.14 \\
\cline { 2 - 4 } & Moderate & 17 & 58.62 \\
\cline { 2 - 4 } & Severe & 5 & 17.24 \\
\hline
\end{tabular}

Table VII

Evolution of MMSE score according to the treatment

\begin{tabular}{|l|l|c|}
\hline \multicolumn{1}{|c}{ Treatment } & Evaluation & MMSE score \\
\hline \multirow{2}{*}{$\begin{array}{l}\text { Donepezil with } \\
\text { Memantine }\end{array}$} & Baseline & $16.37 \pm 5.18$ \\
\cline { 2 - 3 } & At 12 weeks & $16.07 \pm 4.72$ \\
\cline { 2 - 3 } Rivastigmine with & ES & 0.06 \\
\cline { 2 - 3 } Memantine & Baseline & $16.58 \pm 5.34$ \\
\cline { 2 - 3 } & At 12 weeks & $15.68 \pm 4.81$ \\
\cline { 2 - 3 } Galantamine with & ES & 0.17 \\
\cline { 2 - 3 } Memantine & Baseline & $16.64 \pm 5.32$ \\
\cline { 2 - 3 } & At 12 weeks & $15.82 \pm 4.75$ \\
\hline \multirow{3}{*}{ Memantine } & BS & 0.15 \\
\cline { 2 - 3 } & At 12 weeks & $15.11 \pm 4.80$ \\
\cline { 2 - 3 } & ES & 0.24 \\
\hline
\end{tabular}

Values are represented as mean \pm SD $(n=140$ patients in study group)

Dementia is a disease with increased incidence among the elderly population, it is usually installing after the age of 65 , having prevalence estimated by most studies of 5\% for the $65-80$ age group and of $20-25 \%$ over the age of 80 years old [3]. The most common form of dementia is Alzheimer's disease, it represents about $60 \%$ of all dementia types. Practically from 65 to 85 years, the incidence of the disease doubles at periods of about 5 years $[14,15]$. Women are at a higher risk of developing Alzheimer's dementia, according to studies and literature data, including also the fact that they live longer than men [13]. In menopause oestrogen level decreases [2, 23, 24]; the role of oestrogen in Alzheimer's dementia remains controversial $[9,15]$. The comorbidity of elderly dementia with numerous somatic disorders is almost a rule $[17,26]$. Long-term population studies have indicated that increased blood pressure (BP), especially in midlife, is associated with an increased risk of dementia in the late-life. Several autopsy studies have highlighted a link between hypertension, amyloid plaques, and neurofibrillary gheps - neurofibrillary tangles (e.g. Honolulu-Asia Ageing Study-HAAS) [7, 8]. Hypertension was also associated with increased cerebral atrophy. Therefore, in addition to the risk factor for cerebrovascular injury, hypertension is also related to neurodegenerative changes $[3,7,25]$.

Various vascular conditions, such as heart failure, have been associated with Alzheimer dementia [26]. The presence of coronary artery disease at autopsy has been associated with an increase in cortical senile plaques. In the Rotterdam study, generalized atherosclerosis was also associated with Alzheimer dementia $[4,6,16]$.

The involvement of vascular etiopathogenic, toxic and metabolic factors explains the ineffectiveness of current therapeutic strategies addressed to cognitive/ noncognitive psychopathological domain. This study confirms that the best cholinergic strategy includes the class of compounds known as cholinesterase inhibitors; they have demonstrated measurable effects, albeit modest in cognitive, behavioural and daily activities. We support the idea that the etiopathogenic treatment currently based on substances that augment acetylcholine function should be precocious.

It is necessary to individualize therapy, in order to correct the cognitive disorders and the associated disorders (depression, psychotic and behavioural disorders).

Other randomized clinical studies were analysed, double-blind, placebo-controlled using memantine or donepezil alone or in combination, compared to placebo in moderately severe AD [12]. Memantine and donepezil lead to an improvement in moderate to severe AD and the choice of one of the compounds should be based on their contraindications rather than the severity of the disease. The heterogeneity of SRC screening conditions, the relatively short observation time ( $24-52$ weeks), as well as the various cognitive assessment tools used, did not allow comparisons between different studies.

The limitations of the study are represented by the short period of observation of the treatment effects and the small group of patients, as well as the various doses of medication within each study group, this may not allow a proper comparison concerning treatment response between the studied groups.

\section{Conclusions}

The treatment effect managed very little to stop the MMSE score depreciation. The greatest depreciation effect was achieved with memantine in monotherapy $(\mathrm{ES}=0.24)$, and the lowest with donepezil therapy in combination with memantine ( $\mathrm{ES}=0.24)$.

The results of this study prove that specific antidementia treatment is effective for the treatment of cognitive impairment, especially if instituted at the onset of the disease. 


\section{References}

1. Abdel-Daim MM, Zakhary NI, Aleya L, Bungău SG, Bohara RA, Siddiqi NJ, Aging, metabolic, and degenerative disorders: Biomedical value of antioxidants. Oxid Med Cell Longev., 2018; 2018: 1-2.

2. Bumbu A, Paşca B, Ţiţ DM, Bungău S, Bumbu G, The effects of soy isoflavones and hormonal replacing therapy on the incidence and evolution of postmenopausal female urinary incontinence. Farmacia, 2016; 64: 419-422.

3. Bunn F, Burn AM, Goodman C, Rait G, Norton S, Robinson L, Schoeman J, Brayne C, Comorbidity and dementia: a scoping review of the literature. BMC Med., 2014; 12: 1-15.

4. Chaker L, Wolters FJ, Bos D, Korevaar TIM, Hofman A, van der Lugt A, Koudstaal PJ, Franco OJ, Dehghan A, Vernooij MW, Peeters RP, Ikram MA, Thyroid function and the risk of dementia, The Rotterdam Study. Neurology, 2016; 16(87): 16881695.

5. Cheng X, Zhang L, Lian Y-J, Molecular targets in Alzheimer's disease: From pathogenesis to therapeutics. Biomed Res Int., 2015; 2015: 1-6.

6. Engelhart MJ, Geerlings MI, Meijer J, Kiliaan A, Ruitenberg A, van Swieten JC, Stijnen T, Hofman A, Witteman JCM, Breteler MMB, inflammatory proteins in plasma and the risk of dementia. The Rotterdam Study. Arch Neurol., 2004; 61(5): 668-672.

7. Fodor K, Tit DM, Pasca B, Bustea C, Uivarosan D, Endres L, Iovan C, Abdel-Daim M, Bungau S, Long-term resveratrol supplementation as a secondary prophylaxis for stroke. Oxid Med Cell Longev., 2018; 2018: $1-10$

8. Gelber RP, Launer LJ, White LR, The HonoluluAsia Aging Study: epidemiologic and neuropathologic research on cognitive impairment. Curr Alzheimer Res., 2012; 9: 664-672.

9. Gibbs RB, Aggarwal P, Estrogen and basal forebrain cholinergic neurons: implications for brain aging and Alzheimer's disease-related cognitive decline. Horm Behav., 1998; 34(2): 98-111.

10. Kerry E, Alzheimer's: Proven tips and techniques on how to prevent, delay, detect, and treat the Alzheimer's and dementia disease. Kindle Edition; 2014.

11. Li XL, Hu N, Tan MS, Yu JT, Tan L, Behavioral and psychological symptoms in Alzheimer's disease. Biomed Res Int., 2014; 2014: 1-9.

12. Li X, Song D, Leng SX, Link between type 2 diabetes and Alzheimer's disease: from epidemiology to mechanism and treatment. Clin Interv Aging., 2015; 10: 549-560.

13. Mielke MM, Vemuri P, Rocca WA, Clinical epidemiology of Alzheimer's disease: assessing sex and gender differences. Clin Epid., 2014; 6: 37-48.

14. Molino I, Colucci L, Fasanaro AM, Traini E, Amenta $\mathrm{F}$, Efficacy of memantine, donepezil, or their association in moderate-severe Alzheimer's disease: A review of clinical trials. Sci World J., 2013; 2013: 1-8.

15. Moisescu RE, Ghiță ICV, Sorescu A, Coman OA, Coman L, Fulga I, Cholinergic modulation of memory. Farmacia, 2018; 66(6): 938-947.

16. Oksman M, Iivonen H, Hogyes E, Amtul Z, Penke B, Leenders I, Broersen L, Luetjohann D, Hartmann $\mathrm{T}$, Tanila H, Impact of different saturated fatty acid, polyunsaturated fatty acid and cholesterol containing diets on beta-amyloid accumulation in APP/PS1 transgenic mice. Neurobiol Dis., 2006; 23: 563-572.

17. Olayinka OO, Mbuyi NN, Epidemiology of dementia among the elderly in Sub-Saharan Africa. Int $J$ Alzheimers Dis., 2014; 2014: 1-15.

18. Onose G, Teoibaş-Șerban D, Popescu C, Andone I, Brumă E, Mihăescu A, Haras M, Bumbea AM, Anghelescu A, Spircu T, Badiu C, Daia C, New approaches regarding the use of Actovegin $^{\circledR}$ in subacute/postacute/subchronic traumatic brain injury patients. Farmacia, 2017; 65(5): 772-777.

19. Rizzi L, Rosset I, Roriz-Cruz M, Global epidemiology of dementia: Alzheimer's and vascular types. Biomed Res Int., 2014; 2014: 1-8.

20. Romanian Society of Neurology and Alzheimer's Romanian Society. Diagnostic and Dementia Treatment Guide. Med Publ House AMALTEA. 2007.

21. Seshadri S, Wolf PA, Beiser A, Au R, McNulty K, White R, D'Agostino RB, Lifetime risk of dementia and Alzheimer's disease. The impact of mortality on risk estimates in the Framingham Study. Neurology, 1997; 49(6): 1498-1504.

22. Thies W, Bleiler L, Alzheimer's disease facts and figures. Alzheimer's Demen., 2013; 9(2): 208-245.

23. Ţiţ DM, Bungău S, Cioară F, Suciu RN, Comparative study on the effects of hormone replacement therapy and phytoestrogens in the prevention of the postmenopausal osteoporosis. Osteoporosis Int., 2015; 26: S245-S245.

24. Ţiţ DM, Bungău S, Iovan C, Nistor Cseppento DC, Endres L, Sava C, Sabău AM, Furău G, Furău C, Effects of the hormone replacement therapy and of soy isoflavones on bone resorption in postmenopause. $J$ Clin Med., 2018; 7: 1-13.

25. Whitmer RA, Sidney S, Selby J, Johnston SC, Yaffe $\mathrm{K}$, Midlife cardiovascular risk factors and risk of dementia in late life. Neurology, 2005; 64: 277-281.

26. Wood AG, Chen J, Moran C, Phan T, Beare R, Cooper $\mathrm{K}$, Litras S, Srikanth V, Brain activation during memory encoding in type 2 diabetes mellitus: A discordant twin pair study. J Diabetes Res., 2016; 2016: 1-10.

27. Xie A, Gao J, Xu L, Meng D, Shared mechanisms of neurodegeneration in Alzheimer's disease and Parkinson's disease. Biomed Res Int., 2014; 2014: 1-8.

28. Zou Z, Liu C, Che C, Huang H, Clinical genetics of Alzheimer's disease. Biomed Res Int., 2014; 2014: $1-10$. 